\title{
VERBAL AND NON-VERBAL EXPRESSIONS IN TRADITION OF MOMBOLASUAKO OF TOLAKINESE AT SOUTHEAST SULAWESI (ETHNOLINGUISTIC'S STUDY)
}

\author{
Ilfan Askul Pehala ${ }^{1}$, Inyo Yos Fernandez ${ }^{2}$, Wakit Abdullah ${ }^{3}$ \\ Magister of Descriptive Linguistics Program \\ Postgraduate of Sebelas Maret University, Surakarta, Indonesia \\ 1'faizsaniyasnaini@gmail.com; ${ }^{2}$ inyofernandez1946@gmail.com; ${ }^{3}$ abdullahwakit@yahoo.com
}

\begin{abstract}
This research aims to classify, describe and explain verbal and non-verbal expressions in eloping tradition (mombolasuako) of Tolaki based on the procession of eloping tradition (mombolasuako) of Tolaki comprehensively. Theories that are used to solve the problem of this research are ethnolinguistics and ethnoscience. Methodologically, the ethnographic method with the Spradely ethnoscience's analysis is used in this. The data includes primary and secondary data that were collected by participant observation and deeply interview. All collected data were analyzed by using Spradely ethno science's analysis and linguistics' analysis. The outcomes of this research include verbal expressions in mombolasuako include verbal utterances, recitation and remark. For non-verbal expressions, they are (1) the tradition objects must be served by bride groom consists of process consist of kalo sara, rembinggare rua mata, sokei, pekopu rua mata, aso mata, pohuku osara, and ihino osara, (2) gestures of tradition casts in the implementation of the traditions process and (3) tradition casts that consist of Tolea, Pamarenda, Puutobu, Puupe'ana and or Pabitara. In the implementation of the mombolasuako's process verbal and non-verbal expressions verbal utterances, gestures and tradition casts that are adapted to tradition.
\end{abstract}

Key words: ethnolinguistics, mombolasuako, Tolaki, verbal and non-verbal expressions

\section{INTRODUCTION}

The language in the cultural life and traditions of the community is a concrete manifestation of the using of language itself. Language is not just about its structure, but the speakers and using of the language are very important analyzed in depth. The speakers refers to the individuals in a social society sphere which tribe or ethnicity. The language using refers to the utterances or verbal expressions and traditions as nonverbal expressions as a form of culture in abstract and concrete forms. Abstract and concrete manifestations of non-verbal utterances are reflected in the objects, folklore, rules and stages in their daily lives.

Ethnolinguistic as the branch of linguistics in interdisciplinary studies explores the verbal expressions and non-verbal expressions of the life of society as part of 
language and culture an ethnic. Foley (1997, p. 3) said that ethnolinguistic or anthropological linguistics is a branch of linguistics concerned with the language in the cultural context and broader social, rule in forging and maintaining cultural practices/ tradition and social structure. Therefore, based on the definitions mentioned by Foley (1997), it became clear that language, the society and its social structure and tradition are things that are inseparable and become part of the studies in anthropological linguistics.

Ethnolinguistic focuses the language dimension in the form of lingual units such as words, phrases, sentences or speech and discourse, or other lingual unit used in the social dimension of culture in the form of ceremony, ritual or otherwise. Often the language dimension is called the verbal expression or language used in the non-verbal expressions, while the non-verbal expression is a form of cultural action such as ceremonies, traditions and so more.

Culture is loaded with verbal expression in practice and involves elements of verbal and non-verbal expressions contained in the Tolaki tribe called osara. It is the rules on what is forbidden to be done and what can be done by a person, the family in the social life of society and government. Osara as non-verbal expressions aims to develop, supervise, regulate and enforce laws and rules for the creation of a safe life, a peaceful and orderly. This is expressed in utterance said "Luwuako nggo nibutuno osara tambuoki suere, nggo tekono ine amboronga nggo-nggo nime'ambo'ako" that meant "All purposes of tradition/its law are for the establishment of law and order, social peace and the welfare of society. Besides, the importance of the Tolaki traditions can be also known in utterance that said "Inae konasara ie pinesara, Inae liasara ie pinekasara" that meant "Whoso keepeth his tradition will be quiet/rewarded, who breaks the tradition will have tribulation".

One manifestation of traditions of this ethnic is in one of their cultural domains, that is in terms of marriage. In Tolaki, there are 3 types of traditions of marriage that begins with the process itself. The process is like making a proposal (mo'awo niwule), eloping (mombolasuako) and caused by adultery where pregnant out of wedlock, was caught and prosecution responsibility of a woman to a man who had made love to her either pregnant or not (melanggahako). The second and the third marriages were preceded by a violation. In eloping (mombolasuako) there are some 
stages such as merembinggare, mesokei, consent granted and mekopu. For melanggahako or mombokomendia (pregnancy outside marriage or adultery) consists of powoka biri, pelanggahako, taa pombonaanaakoa, pekopu and consent granted. All of these are mo'awo niwule (making a proposal or bring betel), eloping (mombolasuako) and melanggahako (marriage caused by adultery or unwed) terminated by mowindahako as the stage of completion and the completion of all tradition affairs. Morally and prevalence, mo'awo niwule is a wedding that fill the standards as morality and injustice which has good value in the society. This is due to their view where the consent of both parties either consensual or betrothed primarily parents who want goodness and happiness to his daughter inwardly and outwardly.

Eloping tradition of Tolaki or mombolasuako is one type of marriage, which until today have been made and can be found in the life of society its main of Tolaki in Konawe whose majority are ethnic Tolaki. Although this marriage is a marriage that is included in the category that begins with the violation (Al-Ashur, 2006, p. 11) and tend to be favored, but this is a recurring phenomenon that occurs in the community of Tolaki tribe and other tribes in the region of Konawe. Mombolasuako (eloping) that falls within the marriage that begins with the customary violations by public of Tolaki is considered more honorable than marriage problems caused by immoral (melanggahako).

Altogether tradition of mombolasuako is a combination of lingual and nonlingual expressions in the form of objects traditions among indigenous implementers that consist of 4 persons namely Tolea, Pamarenda, Puutobu, Puupe'ana and Pabitara which have functions, duties and rights in solving problems on traditions mombolasuako between the woman's (bride) family and the family of man (groom). The Combining of lingual expression or verbal expression and non-lingual or non-verbal expression in the implementation of custom events are called mombesara. Indigenous of Tolaki that is called osara which is a heritage maintained until today, but osara is also influenced by the values of Islam which is the religion of the majority ethnic Tolaki and society in Konawe both in speech as a verbal behavior and objects of customs and gestures when customary speech delivered as non-verbal aspects. Even the nationalist sense, equality and adaptation to modern or contemporary life also influenced in its implementation. But, it does not change the essence of the noble objectives of the 
tradition itself does not conflict with the value of Islam, the Criminal Law and the Constitution of the State. In the implementation of tradition mombolasuako, customary law walked in the tradition process. As for the religious law, it is executed in the process of consent granted between the second pair lovebirds that run this marriage.

In this study, the writer focuses to a domain of marriage traditions that called mombolasuako (eloping). In this one, verbal and non-verbal expressions have main important rules to solve problems that happened on two sides. This problem on both, potentially, can be bigger than before and be open conflict among parents of the bride and their families, the prospective groom and his parents and their families. This can happen because there is disappointment of parents of the bride that hoped their daughter to get better education until undergraduate level. Beside that they also hoped that theirs would get better couple in better educations, has social values and good skill and from good family. These hopes are reasonable and logic caused generally the couples that do mombolasuako are teenagers from Junior High School and Senior High School. They should be in school to get knowledge like people in general, however, this one dashed hopes of their parents. Besides the teenagers, the couples of this marriage are from young man on age range 17 until 25 years old. They are generally students of college or people that are financially and mentally yet have a strong foothold for their lives after marriage.

All these, especially disappointment of parents of the bride that dislike this happening, are often be trouble and have potential physically and psychologically. To solve this and prevent bigger problems, the tradition has important rules to prevent frictions will occur. In the traditions there are steps, event, devices or participants as non-verbal expressions and verbal utterances that will be means of mediations to the parents of bride to be sincere and willing to sit together to find solutions on this happening.

Research or writings that deal verbal and non-verbal expressions in marriage traditions especially mombolasuako (eloping) are rarely done especially from perspectives of linguistic. These can be evidenced from such as Yasmud (2011), Arsamid (2006) and Tamburaka (2015). Most of them more focused to tradition mo'awo niwule (making a proposal) and mowindahako (indigenous settlement), while for mombolasuako (eloping) rarely be discussion on research or writings. Therefore, 
based on all these said before, so many gaps that can be found from this case especially on linguistic perspective that is ethnolinguistic.

For this research, its objects are focused to (i) verbal and non-verbal expressions in marriage tradition of Tolaki that is mombolasuako or eloping and (ii) how are verbal and non-verbal expressions in mombolasuako or eloping able to hammer problems between parents of bride and the groom. In this research, verbal and nonverbal expressions will be classified, described and explained comprehensively. They are so interested to be objects of this research caused verbal and non-verbal expressions are just not language only. They are representation of mindset of a tribe, in this case is Tolakinese, in solving problem and become the way and be only one to solve problem and prevent it wider. By verbal and non-verbal expressions, all problems from mombolasuako or eloping will be finished wisely and equitably.

\section{THEORIES AND METHODS}

Theory in this research is based on etnolinguistic theories by Foley (1997). This research employed descriptive qualitative method because "qualitative descriptive study conducts careful observation and recording meticulous number of phenomena related to the problems examined." (Subroto, 2012, p. 31). This method is suitable also for ethnolinguistic that aims to reveal and describe a variety of qualitative information through the depiction or description of a careful and clear in describing clearly and in detail of the nature of a case of individuals or groups. Besides, it conducts also a careful observation and recording of conscientious number of phenomena related to the problems examined primarily verbal and non verbal expression to an ethnicity.

The used data in this research were taken from participant observation and indepth interviews. The data of this research were transcribed in lingual units such as words, phrases, clauses and sentences. They, then, were analyzed in two analysis methods. First method was linguistics' analysis and then used new ethnographic method Spradely (2007) or ethnoscience for clearer descriptions and explanations of data taken before. Beside that all data, then, were explained formally and informally. In the formal methods, data are presented in the form of signs, symbols, maps of the area, drawings, photographs, charts, tables and more. Meanwhile, the informal method data are presented in word or regular expression without the use of signs and symbols that normally are certain mathematically (Sudaryanto, 2015, p. 241). Presentations of the 
results of the analysis are formally and informally expected to provide a clearer explanation of this thesis (Abdullah, 2013).

\section{FINDINGS AND DISCUSSIONS}

The findings of this research are presented in four main parts, namely parts of stages in mombolasuako, verbal expressions of mombolasuako, non-verbal expressions of mombolasuako and roles of expressions and non-verbal expressions in mombolasuako.

\section{Parts of stages in mombolasuako}

Mombolasuako as one of the indigenous of tribes Tolaki wedding tradition consists of three stages that are all related to each other. Each stage has a purpose and function in an attempt to quell the issue between the parents of the bride and groom before. Mombolasuako or molasuako means carried off or eloping. When it was segmented by the morpheme elements of forming these words, morpheme molasu categorized verb means run. When it get confix $-m b o-+-k o$ or suffix $+-k o$ means acts committed by a man against a woman by taking her to places of $o^{\prime}$ Ima (headman or village priest) or Puutobu that they will be given protection by the government and indigenous to marry so that the elderly women and men who do not know this and take care of their religious marriage and traditionally then to the general public interpreted as eloping. Before going to places of o'Ima, they had promised to each other to go there based on a predetermined time. When they had arrived, they will stay there for a period until mesokei are done and not allowed or banned in room together.

These stages consist of merembinggare, mesokei and mekopu. Merembinggare phase serves as a way to inform the parents of the woman with the boy/man who had been carried away by a man who intends to make her daughter as his wife. This notification is done by a family man who did this with the help of the indigenous, religious leaders and had been known previously by the authorities or the leaders of the region (the government) in the area of the woman's parents live. The main objective of this phase is to spread the purpose of their visit and the state of his word and asked the parents of the girls to get ready for the arrival of the bride family man in the next stage so that this problem was quickly resolved. When this has been done, the family of the 
bride is going consult and prepare for the arrival of the prospective family of the bridegroom at a later stage.



Picture 1. Stages of Mombolasuako

The next step of mombolasuako is mesokei which is a stage to solve problems that previously carried out by the prospective bridegroom. This stage is important because it is a way for parents bride receives prospective bridegroom as their son-of-law through the expression of verbal and non-verbal that functions and specific objectives as well as evidence seriousness towards their daughter and apologized for what they had done before. In addition, in this stage is going to also discuss what will be provided by the family of bridegroom. In this stage, the family of the prospective groom is accompanied by implementing of tradition that is Tolea as their spokesman with several sub stages mesokei as phases of tradition and continued with the consent granted as well as the cancellation of ablution as a stage to marry the prospective groom and bride to be legitimate religious, tradition and state law. In another side, the family of the bride will be accompanied by government agencies (Pamarenda), indigenous parties as judge and giver instructions (Puutobu) and representatives (Puupe'ana) or their spokesman (Pabitara). they will receive a tradition submitted by the prospective bridegroom and negotiate what to do and what will be carried by the bride in the stage of completion of tradition or mowindahako. With mesokei stage, the disgrace and disaster that can happen because of what they have done before will be removed because it has been resolved with the laws and regulations in force in the community. 
After mesokei carried out in which the stages of tradition, the consent granted and cancellation of ablution are done, the next step is mekopu means embraced. Mekopu, if it's segmented morphologically consists of two morphemes namely me- + as a prefix and morpheme кори as a basis for the establishment of the next word that means hug or cuddle (verb). Morpheme kopu also appears in the words of verbs kopu'i (hugs him), nikopu (embraced) and kinopu (carried). In addition, when kopu morpheme is attached to the prefix pe- be pekopu, it is categorized into nouns which relate hug to the meaning of the objects used in the mesokei that is pekopu rua mata (2 pieces of gloves) as a symbolic apology to the child's parents of the girl.

Mekopu is the last stages of tradition's event mesokei that is marked with an apology as he knelt in front of her parents and hugged and kissed them on their left and right cheeks. Mekopu process is no longer involves Tolea, Pamarenda, Puutobu, Puupe'ana, Pabitara and o'Ima; so that no speech spoken by them. This means mekopu is part of the parents and children who do mombolasuako. Mekopu is done after the consent granted or the marriage contract is done. After the marriage ceremony performed, parents of women and men will be called and be seated at the ceremony takes place. After they were seated, the two couples who have been married official would sit cross-legged in front of them and are welcome to ask for forgiveness and hugging their parents. Mekopu is starting from the girl's mother and father and then to proceed again to the boy's mother and to the father. They (boys and girls) will also greet the people in the room such as Tolea, Pamarenda, Puutobu, Puupe'ana, Pabitara, o'Ima and their closer kin in it.

After their daughter and their son-of-law apologized to them or mekopu, the groom's parents would also apologize and hug the bride's parents. They expressed deep regret of this matter and requested that the mutual affection devoted to each other and guide their children. On the basis of the incident emotionally draining it is, the stages mesokei is most poignant stage due to guilt and longing for the girl who had hurt her parents by action mombolasuako where there is a sense of hurt or did not accept his parents for what they have done in the past before.

After mesokei and consent granted were done, the disappointment or denial of parental bride to their son-in-law and instead of the parents of the bridegroom to their daughter-in-law or otherwise should they buried because they have been processed in 
tradition and lawfully religion and formal. In other words, shame and anger that occurs before mesokei was done will recede and outages because they have officially became husband and wife that legitimated religious, legal and protected by law as witnessed by the government and accepted socially and avoid disgrace and a byword wider community because it is processed according to the rules of traditionally law. Even if they have pain and do not accept it, it had gone. Then it is a matter between them personally and to God. Indigenous is just trying to finish the case and looking for a way out and not to change the character and nature of a person.

\section{Verbal expressions of mombolasuako}

Verbal expression in tradition of mombolasuako is not only on verbal utterances delivered by the Tolea to Pamarenda, Puutobu, Puupe'ana and Pabitara as their way of diplomacy, negotiation and deliberation. Moreover, verbal expressions also involve remark and recitations in the process of the solemnization of marriage and the cancellation of ablution. However, for mekopu, it is not necessary needed because nonverbal expression used in this. Verbal utterances in the process of mombolasuako are based on sub-stages in the process of mombolasuako. Merembinggare as early stages contains verbal utterance that was delivered by Tolea to Pabitara that inform to him about their subject. Excerpt from verbal utterance was spoken by Tolea is as follows:

"Tudu ino saranggu. Metudungge ino te'eni rua mata pinopakoino osara. Kelaa takinimiu ilaikamiu, iyamoto ipeokahongge. Ki'oki nolaa salakolakono, oki nolaa sadongga-donggano. Batuano, oki nolaa tinanu kiniku, oki nolaa nosora'i bokeo, oki nolaa noduu'i o'ule. Mano laa'ito ine pamarenda, ni'uneno osara"

(Has stretched indigenous me this. Stretched over two points before the destination of tradition. If there is anything (girl) that you do not see in your home is, do you ask where she is (worried). It is not she lost, she does everywhere. In that sense, she isn't on headlong buffalo, she isn't also killed the alligator/crocodile, she isn't also swallowed a snake. But she is being in under the protection of the government, in the shade of tradition's law). 
Table 1. Verbal expressions in stages of mombolasuako

\begin{tabular}{|c|c|c|c|c|}
\hline \multirow[b]{2}{*}{ Stages } & \multirow[b]{2}{*}{ Sub stages } & \multicolumn{3}{|c|}{ Verbal expressions } \\
\hline & & $\begin{array}{c}\text { Verbal utterances based } \\
\text { on the stages }\end{array}$ & Remarks & recitations \\
\hline Merembinggare & - & Merembinggare & - & - \\
\hline \multirow{18}{*}{ Mesokei } & \multirow{10}{*}{ Mesokei } & $\begin{array}{c}\text { sara wonua } \\
\text { pombesanggari }\end{array}$ & - & - \\
\hline & & sara wonua pomberahi & - & - \\
\hline & & sara pombepende & - & - \\
\hline & & handover of sokei & - & - \\
\hline & & $\begin{array}{l}\text { discussion of } \\
\text { mowindahako }\end{array}$ & - & - \\
\hline & & $\begin{array}{c}\text { negotiations of } \\
\text { pinesambepeako/lawasara }\end{array}$ & - & - \\
\hline & & $\begin{array}{l}\text { the timing of } \\
\text { mowindahako }\end{array}$ & - & - \\
\hline & & handover pekopu & - & - \\
\hline & & discussion of pinakawi & - & - \\
\hline & & pondotokino osara & - & - \\
\hline & \multirow{7}{*}{$\begin{array}{l}\text { solemnization of } \\
\text { marriage }\end{array}$} & \multirow{7}{*}{ - } & $\begin{array}{c}\text { Submission of } \\
\text { credentials }\end{array}$ & - \\
\hline & & & \multirow{6}{*}{$\begin{array}{l}\text { solemnization of } \\
\text { marriage }\end{array}$} & Sura Al-Fatihah \\
\hline & & & & Sura Al-Ikhlas \\
\hline & & & & Sura An-Nas \\
\hline & & & & Sura Al- Falaq \\
\hline & & & & Istighfar \\
\hline & & & & $\begin{array}{c}\text { Confession of } \\
\text { Allah (syahadat) }\end{array}$ \\
\hline & $\begin{array}{c}\text { cancellation of } \\
\text { ablution } \\
\end{array}$ & - & - & $\begin{array}{c}\text { Confession of } \\
\text { Allah (syahadat) }\end{array}$ \\
\hline Mekopu & - & - & - & - \\
\hline
\end{tabular}

Source: processed primary data

The Family and Parents of groom

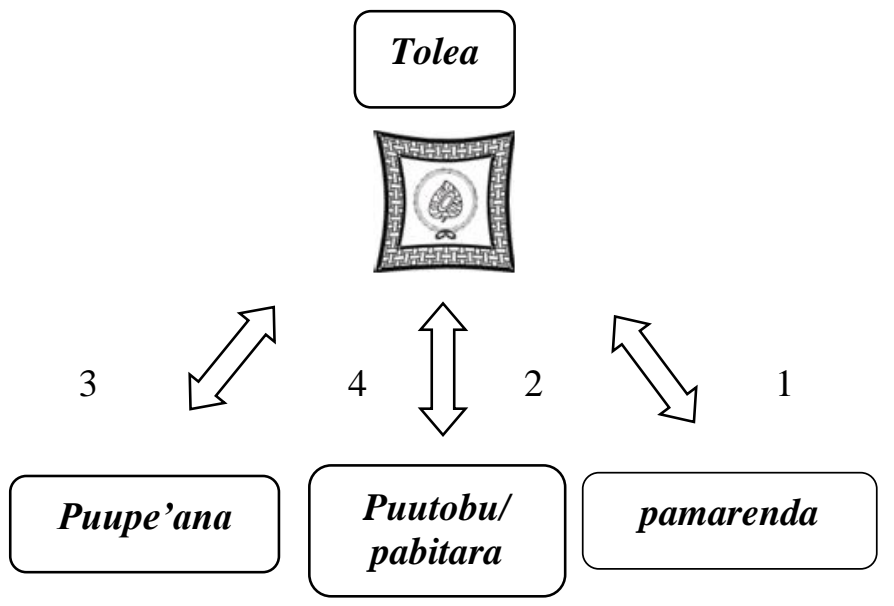

The Family and Parents of bride

Picture 2. Direction of Verbal Utterances in Mesokei 
Verbal utterances in the process of mesokei are also determined by the sub stages in it. Sub-stages of this process will determine how the object and purpose of Tolea to Pamarenda, Puutobu, Puupe'ana and Pabitara. The verbal utterances consist of sara wonua pombesanggari (application for license to Pamarenda/government), sara wonua pomberahi (application for license to Puutobu/indigenous judges) and sara pombepende (application for license to Puupe'ana/representative of the bride's parents), handover of sokei, discussion of mowindahako, negotiations of pinesambepeakol lawasara, the timing of mowindahako, pekopu handover, discussion of pinakawi and pondotokino osara (the closing of ceremony).

Remark in the process of consent granted is delivery of the mandate from the bride's father or her brother or her uncle (when the bride's father had died) to the prince. Then, the recitations were spoken by the prospective bridegroom in the marriage ceremony prior consent granted such as 4 sura in the Quran that are Al-Fatiha, AlIkhlas, An-Nas and Al-Falaq. After they are done, they will be connected with uttering istighfar for 3 times and shahada for 3 times too as well as the meaning of the creed and continued by saying the consent granted. After the consent granted, then the subsequent cancellation of ablution is performed by saying the syahadat by the bridegroom and his woman.

\section{Non-verbal expressions of mombolasuako}

Non-verbal expressions in tradition of mombolasuako consist of three types: (1) the objects used in the process of tradition and wedding process, (2) the body movements of the participants were done during at the process of tradition and wedding process, and (3) the major participant in the process of tradition of (Tolea, Pamarenda, Puutobu, Puupe'ana or Pabitara) and in the process of marriage (the prince, the groom, the bride and the father of the bride). They are based on three phases and sub-phases and all these determine how verbal expression was done. On the basis of this, it can be said that the linguistic expressions of indigenous mombolasuako in verbal and nonverbal expressions determined by non-verbal expression.

The objects used in the process of mombolasuako are distinguished into indigenous traditions and wedding process. In the traditional process, objects consists of 5 items such as kalo sara, gloves, shroud, buffalo and money. These objects are then adapted to the stage in the traditionally law of mombolasuako. In stage of 
merembinggare, the traditions' objects that are presented comprise reply kalo sara, aso mata (money amounted to Rp. 10,000 as a tribute to the objectives of the tradition of that are served and an early sign of traditionally starts) and rembinggare rua mata (2 pieces of gloves), each of which is pombongu okae (binder hand-shaped piece of glove) and pombongu okare (fastener-shaped foot piece of glove). At stage of mesokei, objects are being used more than ever consisting of kalo sara, aso mata (money amounted to Rp. 10.000 - Rp. 20.000), sokei (consisting of aso ndumbu okasa (a bundle shroud), aso kiniku (a buffalo converted into Rp. 250,000) and pekopu rua mata (2 pieces of gloves)). Pekopu rua mata (2 pieces of gloves) as a symbol of apology of bride to his mother and father and pondotokino osara (money amounted to Rp. 100,000) that was inserted into 3 envelops for Pamarenda, Puutobu, Puupe'ana or Pabitara. In the process of marriage after the tradition process in mesokei had taken place, the objects used are popolo (dowry) amounted to Rp. 264,000 and 2 glass cups of drinking water were placed in a container that will be used in the cancellation of ablution guided by the prince.

Table 2. Non-Verbal expressions in stages of mombolasuako

\begin{tabular}{|c|c|c|c|c|}
\hline \multirow[b]{2}{*}{ Stages } & \multirow[b]{2}{*}{ Sub stages } & \multicolumn{3}{|c|}{\begin{tabular}{|l} 
Non-Verbal expressions \\
\end{tabular}} \\
\hline & & Objects used & $\begin{array}{c}\text { body } \\
\text { movements }\end{array}$ & major participant \\
\hline Merembinggare & - & $\begin{array}{l}\text { Kalo sara, aso mata and } \\
\text { rembinggare rua mata }\end{array}$ & $\checkmark$ & Tolea and Pabitara \\
\hline \multirow{3}{*}{ Mesokei } & Mesokei & $\begin{array}{l}\text { Kalo sara, aso mata, sokei, } \\
\text { pekopu rua mata and } \\
\text { pondotokino osara }\end{array}$ & $\checkmark$ & $\begin{array}{l}\text { Tolea, Pamarenda, } \\
\text { Puutobu, Puupe'ana } \\
\text { or Pabitara }\end{array}$ \\
\hline & $\begin{array}{l}\text { solemnization } \\
\text { of marriage }\end{array}$ & Popolo (dowry) & $\checkmark$ & $\begin{array}{l}\text { Bride's father, } \\
\text { headman and groom. }\end{array}$ \\
\hline & $\begin{array}{c}\text { cancellation } \\
\text { of ablution }\end{array}$ & $\begin{array}{l}2 \text { glass cups of drinking water } \\
\text { and their container }\end{array}$ & $\checkmark$ & $\begin{array}{l}\text { Headman, bride and } \\
\text { groom. }\end{array}$ \\
\hline Mekopu & - & & $\checkmark$ & $\begin{array}{l}\text { Bride, groom and } \\
\text { their parents }\end{array}$ \\
\hline
\end{tabular}

Source: processed primary data

The second non-verbal expression in the tradition of mombolasuako is the movement of the body. It is in the process of implementation of the tradition of and movements of the body in the process of marriage that is in the process of consent granted and cancellation of ablution. In the process of indigenous, indigenous body movement occurs when served from Tolea to Pamarenda, Puutobu, Puupe'ana and Pabitara. The serving process of this tradition occurs in the process of merembinggare and mesokei those are in the process of implementation of the tradition of like sara wonua pombesanggari (application for license to Pamarenda / government), sara 
wonua pomberahi (application for license to Puutobu / indigenous judges) and sara pombepende (application for license to Puupe'ana / representative of the bride's parents), handover of sokei, discussion of mowindahako, negotiations of pinesambepeako / lawasara, the timing of mowindahako, handover of pekopu rua mata, discussion of pinakawi and pondotokino osara (the closing of ceremony). Movement of processes in wonua sara pombesanggari (application for license to Pamarenda / government), sara wonua pomberahi (application for license to Puutobu / indigenous judges) and sara pombepende (application for license to Puupe'ana / representative of the bride's parents) are inspired and adapted from body movement while performing prayers (shalat) from takbir until the end, takhiyat, while the movement in another stage is adapted from the motion of takhiyat too. At the final stage of the pondotokino osara (the closing of ceremony), the motion is Tolea will rotate kalo sara to the left and face to Pabitara and vice versa Pabitara to Tolea.

In the process of the consent granted, the headman will change his cross-legged sitting position to a sitting position with her right leg and left leg squat is folded to the right and the left leg pressing buttocks. The sitting position is almost like sitting takhiyat with the right leg squat. Both of their right feet will touch each other. For the position of the hand, right hand principalities and the prospective groom then shook hands like a fist in the arm wrestle with the thumb touching. Both of their right hands covered with a cloth, while their left hands on the left side of the body to maintain balance. For cancellation of ablution, the bridegroom was taken to the room where the bride is awaiting. They will sit facing each other mediated by a tray on which there are two cups of water. In the middle of them, the headman will hold their right hands while reciting the creed of times, turning to each bride. After that they will also read the creed. The groom say "Asyhadu'ala ilaha ilallah" and directly connected by the bride by saying " wa'asyhadu anna Muhammad rasulullah". After the recitation of the Creed from them, the headman plunged their right thumbs and pushed them into the glass until the glasses are falling together and spilling water. At the same time, the bride and groom's right handed directly to one another. Then, their thumbs will touch their chest or forehead partner. Thus, they have been kosher to each other.

At the stage of mekopu, body movements of couples that have been officially married is sitting cross-legged in front of their parent and ask their forgiveness and huge 
them. Mekopu is starting from the bride's mother and her father and then to proceed again to the groom's mother and his father. They will also greet the people in the room such as Pamarenda, Puutobu, Puupe'ana, Pabitara, o'Ima and their kin in it. After their children apologized to them, the groom's parents would also apologize and hug the bride's parents. They expressed deep regret on this matter and requested that the mutual affection devoted to each other and guide their children.

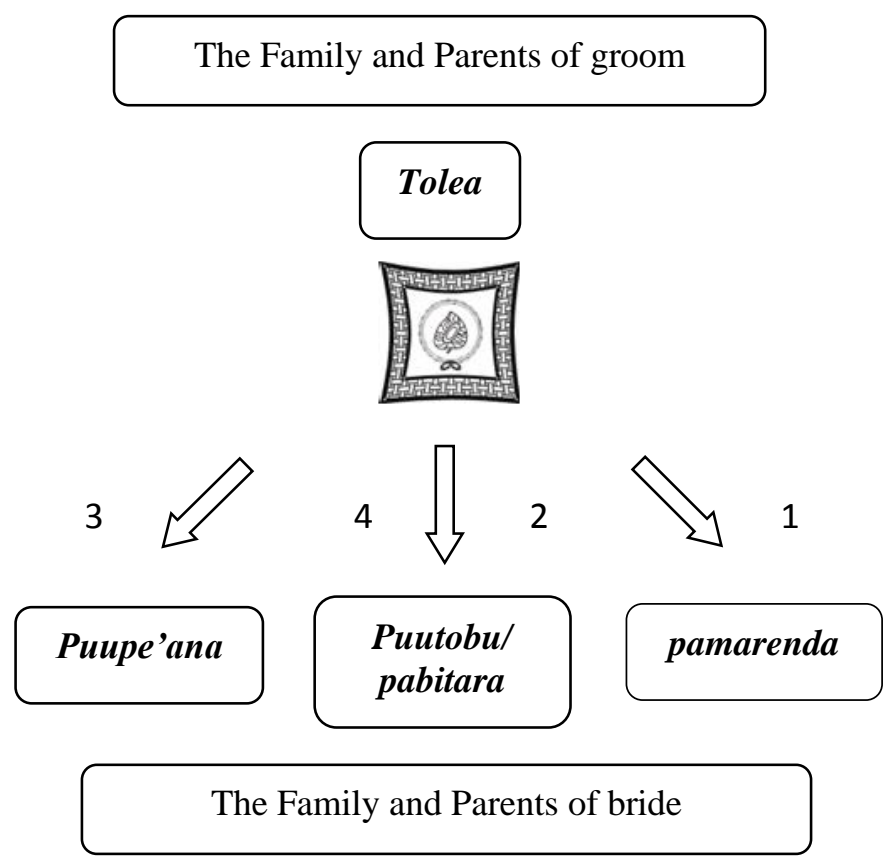

Picture 3. Direction of a Non-Verbal Expressions (Kalo sara) in Mesokei

The third verbal expression of indigenous tradition of mombolasuako is implementing major participant that consist of Tolea, Pamarenda, Puutobu, Puupe'ana or Pabitara and O'Ima that has duty to marry the couple who eloped. Here is a description of the implementing tradition of or major participant in tradition of mombolasuako, which is as follows: (1) Tolea (Ambassador) is a person who served as a spokesman, deputy parents prospective bridegroom and the server of tradition, (2) Pamarenda (government) namely O'Ima/Lurah (village head) or Odesa/Kepala Desa (village head) or represent them as the official ruler tradition of the region and community leaders, (3) Puutobu (judge of tradition) as hint giver of instructions and to mediate in the case of tradition, (4) Puupe'ana (deputy of parents bride) as a person who represents the parents of women at once symbolic of mburaha mbulaika (parents' house of the bride) was the venue for indigenous of mesokei, (5) Pabitara (spokesman) 
as those who accept the tradition of and became a spokeswoman for the family of the candidate the bride and (6) o'Ima (Imam village or the village priest who was also headman) contributes to marry men and women who have eloped. In the implementation of tradition, Pabitara and Puupe'ana functionally have the same role or function. However, in reality in a tradition of implementation, Pabitara is sometimes played as a double by Puutobu.

\section{Kalo sara as center of language's expressions of mombolasuako}

In the main of Tolaki wedding traditions' activities includes mombolasuako, there are elements, tools and main media that must exist in the implementation of cultural activities. Objects or non-verbal expression is the life of the indigenous themselves. The object is a symbol, representation and indigenous identity of Tolaki became the distinguishing feature of other indigenous tribes. The thing is kalo sara that consists of kalo, siwole uwa or pondine, white cloth, tawa bite (betel leaf), aso boto inea tonia (1 piece matchmaker). Kalo sara is not just as mere objects into custom symbol only, but it is also the legality of the implementation of the customs and the media to "subdue" the people in dispute to sit together to solve problems that occur.

In marriage tradition's of mombolasuako, kalo sara is only used by Tolea alone. While Pamarenda, Puutobu, Puupe'ana and Pabitara don't use it, but they will received kalo sara as a symbol of respect to laws that runs and as appreciation to the purpose of the law. Tolea uses kalo sara as a medium to ask for permission, submit and ask custom objects that must be met, media for negotiation costs to be used at parties, to determine the appropriate timing of the party and a sign that the customs have been implemented. While the other actors give permission, to accept and to negotiate based on what Tolea do with it. Speech as a verbal expression, gestures when tradition will be made and custom objects that will be submitted, all began, marked and ends with kalo sara. It concluded that kalo sara is tradition representations and symbols of indigenous Tolaki itself. Without kalo sara, custom activities will not be done, verbal utterances can't be uttered, other custom objects are not able delivered and indigenous actors can't play a role.

In the implementation of tradition verbally, kalo sara has a function as a marker of Tolea to Pamarenda, Puutobu, Puupe'ana and Pabitara. The motions of Tolea in lifting and thrusting kalo sara to them according to the classification identifies 
that the movement be a form of respecting and markers permit application that are called wonua pombesanggari sara, sara wonua pomberahi and pombependee. Kalo sara thrusting motion is made by Tolea to them according classification means submission sokei marker, mowindahako discussion, negotiation pinesambepeako / lawasara, timing mowindahako party, pekopu submission, discussion pinakawi (marriage contract) and Pondotokino osara (the end of the traditional procession). Kalo sara twisting to the left by Pabitara or Puutobu and twisting kalo sara to rightward by Tolea indicate that the arrangements have been implemented, the tradition has been received by them and all have been completed.

The motion is done not just affect what will be said and done by Tolea to Pamarenda, Puutobu, Puupe'ana and Pabitara. But, this motion also determine the pace of delivery of custom objects such as rembinggare rua mata (2 pieces of gloves), sokei (a bundle shroud and buffalo are converted into money Rp. 250,000) and pekopu rua mata (2 pieces of gloves). Kalo sara also implies a world view of Tolaki people against Allah or $o^{\prime} \mathrm{Ombu}$ as the macrocosm and microcosm is the forces of nature as a place where they are born, live and die that everything is God's creation. In addition kalo sara represents the heart and of human life in the form of its constituent objects. Human life in the form of life associated with the Creator that Allah SWT., Lives with regard to the community where he lives to socialize and where he lives, breathes, eats, drinks and dies later. That place is a nature created by Allah SWT. sustenance and exams are in the form of disaster, death, tragedy and punishment of actions will he get in the scope of nature. Therefore, the assumption that says that the attitude of "egoism and arrogance" towards indigenous is an attitude that will get a reply in the form of, death, tragedy and punishment. The nature where he lives will impose penalties as intermediaries and God as the Supreme Being himself gives the punishments.

Kalo sara also shows the mindset of the people of the tribe Tolaki based on the classifications, rules and principles of law, the State and indigenous. Kalo sara explicitly shows local wisdom on kalo sara itself that becomes characterizes of Tolaki people in traditions and cultures. Kalo sara becomes the media and an effective mediator for the community of Tolaki in solving problems that occurs and are recognized by the public in Konawe Regency from the government, religious parties, the general public and law enforcement agencies namely the police 


\section{CONCLUSION}

Indigenous mombolasuako (eloping) verbally and non-verbally determines the way in solving the problems that occur. Verbal expression is in the form of oral speech accordance to its stages. This speech is uttered by the actors in the implementation of its events. The speech uses high variation that is used in cultural activities. The words are used to use elusive metaphors and elusive synonyms if their essences and purposes are not understood. Non-verbal expression is in the form of objects that becomes the center of traditional and indigenous objects that must be met as notices, forms sincerity to solve the problem and an apology. The stages of customs in mombolasuako consist of notification (merembinggare), the process of resolving the problem of customary (mesokei), the implementation of the consent granted (pekawi'a) and an apology to the parents (mekopu). These stages are all watched and protected by the government (Pamarenda), religion and customs (osara) as a pillar in the life of society. In addition, the indigenous language and culture in mombolasuako (eloping) are also recognized and appreciated by the government authorities and the police. This tradition is also a way of mediating problems that occur between the families and effective in reducing conflict will occur.

The author fully understands that this research is not perfect and needs more additions. The author is aware of the limitations of ability, time and funds in writing of this research. For better improvement, the authors look forward to other researchers to examine in this research both from similar and different perspective. This is due to lack of research that examines the language and Tolaki's tradition with the linguistic phenomena that exist in society that can't be separated from its owners and its speakers. Besides, the government of Konawe Regency should give attention to this tradition especially in its language or expressions as consideration in efforts to preserve of Tolaki's language and its tradition to young generation especially for the students. This is very important done because Tolaki's language and its tradition as the heritage of ancestors and culture that have been being eroded by the times. This is further exacerbated by the lack of written scientific documentation published to the general public. Therefore it is resulting in a lack of interest in learning Tolaki's language and tradition as local genus and its wisdom. People need to re-understand the purpose, essence and value of tradition of mombolasuako of Tolakinese. This one is often 
misunderstood, discredited and disparaged as tradition that gives bad influence, obsolete, materialistic, complicates as a person's liabilities and tends to lead deviation.

\section{REFERENCES}

Abdullah, W. (2013). Kearifan lokal dalam bahasa dan budaya jawa masyarakat nelayan di pesisir selatan kebumen (sebuah kajian etnolinguistik) (doctoral dissertation). Surakarta: Postgraduate of Sebelas Maret University.

Al Ashur, A. (2006.) Hukum adat perkawinan Tolaki: rumusan kajian hasil temu budaya. Unaaha: LAT

Folley, W. A. (1997). Anthropological linguistics: An introduction. Sydney: Blackwell Publishers.

Spradely, J. P. (2007). The Ethnographic interview. Yogyakarta: Tiara Wacana.

Subroto, E. (2012). Pengantar studi semantik dan pragmatik (buku 1. pengantar studi semantik).Surakarta: Cakrawala Media.

Sudaryanto. (2015). Metode dan aneka teknik analisis bahasa: Pengantar penelitian wahana kebudayaan secara linguistis. Yogyakarta: University of Sanata Dharma Press.

Tamburaka, B. (2015). Hukum adat perkawinan Tolaki. Kendari: CV. Barokah Raya

Yasmud. (2011). Tradisi lisan mowindahako Suku Tolaki di Sulawesi Tenggara (master's thesis). Depok: Postgraduate of University of Indonesia 